\title{
Klaus Benesch*
}

\section{Space, Place, Narrative: Critical Regionalism and the Idea of Home in a Global Age}

DOI 10.1515/zaa-2016-0008

Abstract: How to become modern and, simultaneously, return to sources, how to integrate historical progress and the preservation and availability of cultural traditions has been variously described as a major dilemma of modernity. Underlying this dilemma are differing notions of home and of the role of places and regions in a staggeringly globalized, technology-driven civilization. Regionalist movements, such as Agrarianism in the South of the US, have thrived on their antipathy to a fast changing modern world; they have also promulgated a renewed sense of place and a return to regional history and traditions. The essay discusses critical regionalists' celebration of the local and the region; in so doing it also looks at two representatives of opposing notions of home in modernity, Martin Heidegger and Emmanuel Levinas. Finally, it contends that it is primarily by way of narrative and storytelling that a sense of place, of being-in-the-world can be reconstructed.

Everything essential and everything great originated from the fact that man had a home and was rooted in tradition. Martin Heidegger, “Only a God Can Save Us” (1966/1976)

One's implementation in a landscape, one's attachment to Place, is the very splitting of humanity into natives and strangers. Emmanuel Levinas, “Heidegger, Gagarin, and Us” (1963)

\section{Introduction}

In his introduction to the Sierra Club edition of The Unsettling of America, social activist and writer Wendell Berry discusses a rather telling fact of American history, namely, that both the nation's history and its people have often not been driven by an intention to be in the New World. From the start, Americans had no

\footnotetext{
*Corresponding author: Prof. Dr. Klaus Benesch, Department of English and American Studies, University of Munich (LMU), Schellingstr. 3/VG, 80799 München, Germany, e-mail: klaus.benesch@lmu.de
} 
intention to settle, to be where they - often inadvertently - ended up being. Significantly, if also somewhat paradoxically, the settling of the New World had been undertaken by men and women in transit. "As a people," Berry argues, "wherever we have been, we have never really intended to be” (Berry 1978, 3). Early explorers were largely interested in gold not land, and Berry aptly notes that conquests and settlements have been incidental, not central, to this search. Even when much of the 'unknown' geography of America was finally mapped, the dynamics of the frontier translated, for one, into the new myth of an ever-growing industrial market place and, for another, into the promise of unfettered individual mobility associated with American car culture. ${ }^{1}$ Both cultural forces kept Americans mobile and, more often than not, drove them away from where they have settled and taken roots.

Small wonder that Americans rarely conceived of their nation as a place but a continent, a vast space unified by a political geography that always already transcended the notion of cities, regions, or even a country. For the writers of the American revolution, as Cecelia Tichi points out, the nation "assumed specific geographic definition on a continental scale” (Tichi 1979, 77). "This [i.e. the revolution] is not the affair of a city, a country, a province, or a kingdom," Thomas Paine writes in his best-selling pamphlet Common Sense, "but of a continent - of at least one-eighth part of the habitable globe” (qtd. in Tichi 1979, 78). Hardly any of the founding texts of the revolutionary period describe the struggle for independence as merely an American or local event. Rather, they stress the global significance of the revolution by translating concrete places into emblems of a larger transnational scheme. Even if the Puritan typological tradition of historical interpretation had prepared Americans to interpret the founding of the nation on such a world historical, epoch-making scale, the disregard for places, regions, and concrete geography in American history is nevertheless striking.

Yet exceptions to America's glaring inattentiveness to place are equally noteworthy. While critics are wont to connect the nation's economic success to the free flow of humans and ideas across borders, resistance to an increasingly homogenous, transnational cultural space has been widespread. Just consider the persistence of regionalist movements that can be found throughout modern America. Early twentieth-century Agrarianism in the South of the US is a case in point here. In the eyes of the so-called Southern Agrarians, a group of twelve poets and intellectuals associated with Vanderbilt University in Nashville, Tennessee, who in 1930 published a fervent indictment of America's industrial civilization,

1 For the modern frontier(s) of technology, urban planning, and mobility, see Nye (1994; 1997). On 'car culture' and its concomitant cultural narratives, see Flink (1975; 1988) and Seiler (2008). 
Americans had become fatally oblivious to local traditions and the history of concrete places. To remedy the nation's rootlessness, Agrarians called for a cultural reawakening, for which the 'old' South would serve as the model and template. To undo the staggering alienation and cultural decline they saw at work in the world around them, the twelve Southerners wanted Americans to look "backward quite as much as they [would] look forward" (Ransom 1977, 13; cf. also Ransom 1934).

What connects the Southern Agrarians with later critical regionalists, antiglobalization activists, or faith-based conservationist writers such as Wendell Berry is a shared belief in regional values and traditions, defiantly invoked to strengthen local identities vis-à-vis an encompassing, globalized consumer culture. Though clearly at odds with modern American society, antimodern interventions such as the Southern Agrarians' are actually vital for processes of modernization. By foregrounding tensions between tradition and progress, between a past all too easily glorified and the challenges of an unknown, malleable future, they address a number of fundamental issues ingrained in modern civilization. What is more, Agrarians' attack on modern America resonates with contemporary eco-critical or anti-capitalist agendas. In spite of its facile embrace of the South and its racial past, Agrarianism thus speaks to widespread concerns about the fast changing social, economic, and technological environments of late capitalism.

A brief comment on the term 'critical regionalism' is in order here. Mainly used in the realm of architecture and urban planning, where it has come to denote a counter movement to the placelessness and lack of identity associated with the modernist International Style, my own use of 'critical regionalism' is somewhat broader than the original coinage. It refers to a panoply of manifestations of a heightened attention to places or a particular geographic region, often accompanied by a critique of globalized capitalist consumer culture. Since regionalism assumes a special relationship between people and places, a relationship that often turns on notions of either having a 'home' or a feeling of 'at-homeness' vis-à-vis one's immediate geo-cultural environment, the shifting idea of home in an increasingly globalized age is crucial to its political agenda. Critical of industrial society and its tendency to emphasize urban agglomerations and to transform the cultural geography of places, regionalists persistently articulated antimodern sentiments about the modern environment. ${ }^{2}$ Not only has modernity been constantly under attack from without, it has also proved not at all impervious to antimodern elements within its own cultural boundaries.

2 For a critical assessment of the movement and its various repercussions in philosophy and the social sciences, see Canizaro (2007), Botz-Bornstein (2010), and Powell (2007). 
If modern science marks one important area where modernity, as Bruno Latour commented, remained incomplete, attachment to places and regions and resistance to their transformation into global cultural spaces are equally stark manifestations of the antimodern. ${ }^{3}$ What is more, the tension between place and space, between sedentary and vagrant forms of culture, seems to be structurally inherent in processes of modernization. If the former (place) are constantly outweighed by the latter (space) thereby allowing for what we think of as progress and growth, places nevertheless matter: as sites of memory and lived traditions they remind us that to be for humans always also means to be there (as in the German $d a$-sein), to be embedded in a concrete geography and its variegated cultural histories.

It is with respect to this latter function that places continue to be tremendously important. As carriers of cultural narratives they provide an antidote to the rampant deracination and homogeneity associated with processes of globalization. It comes as no surprise, then, that with globalization in full swing, narratives of home, regions, and the local are in demand. Quite strikingly, however, real places, the places we know, recognize, and relate to, are often conspicuously absent from these narratives. As in Cormac McCarthy's bestselling novel The Road (2006) they may even be found to foreground unsettled, vagrant characters in search of a home rather than the home itself. Yet in drawing attention to the modern 'homeless spirit,' famously described by Hegel in his Philosophy of History (1837), these narratives, as I show in the concluding section to this essay, redefine the very idea of home. In so doing, they add to an ongoing debate within modern societies over concepts of space and place, vagrancy and dwelling, the global and the local. ${ }^{4}$

To what extent and at what costs places should be allowed to define human existence has also been the issue of a philosophical controversy between the late Martin Heidegger and the Jewish philosopher Emanuel Levinas. Though both thinkers frequently invoke notions of home and dwelling as a fundamental condition of human existence, Levinas appears to be skeptical about the benefits of

3 In his 1991 study We Have Never Been Modern, Latour identifies a number of pre- or $a$-modern elements, what he calls "a proliferation of hybrids," within modernity. In particular, the distinction between nature and culture as a foundational principle of modern forms of knowledge production appears to have been fuzzy all along (Latour 1993, 5).

4 For Hegel the creation of modern subjectivity is a profoundly alienating experience. While man becomes aware of his intellectual independence he also feels estranged from his customary home, in fact now the world of pure thought becomes his home (see Hegel 1956, 269-270). For the notion of modernity as harbinger of a unifying transnational, global civilization at odds with local cultures and traditions, see Schäfer (2001, 301-304). 
being rooted in a particular place or region. Their differences of how to define 'at-home-ness' and to assess its larger philosophical and political implications carry special meaning for narratives of home under conditions of modernity. It is to these differences that I now turn in more detail.

\section{The Modern Dilemma}

The dilemma of becoming modern has been succinctly described by the French philosopher Paul Ricoeur. In a 1961 essay titled "Universal Civilization and National Cultures," Ricoeur notes a fundamental paradox faced by any modern nation subscribed to a universal ideology of historical progress and change: "There is the paradox: how to become modern and to return to sources; how to revive an old, dormant civilization and take part in universal civilization" (Ricoeur 1965, 276). Ricoeur's analysis of what it means to be modern, namely, to shift from old to new, from the past to the future, and from the local to the universal, echoes with many of the issues at stake in critical regionalism. If regionalists define late capitalist modernity as determined by a conflict between local cultures and an increasingly unifying, universal consumer culture, so does Ricoeur. It is thus only fitting that Kenneth Frampton's 1983 regionalist manifesto “Towards a Critical Regionalism: Six Points for an Architecture of Resistance" opens with an extended quotation from Ricoeur's earlier essay. Writing against what he calls a "Megalopolitan development" (Frampton 1983, 17) in the construction of urban spaces worldwide, i.e. the preponderance of the skyscraper and the serpentine freeway, Frampton invokes Ricoeur's notion of a relentless onrush of transnational technical civilization, if only to take it even a step further. While the inexorable victory of universal civilization as described by Ricoeur still appeared porous and "afforded the possibility of maintaining some general control over the shape and significance of the urban fabric" (Ricoeur 1965, 17), some twenty years later the possibility of rescuing locally inflected building traditions and making them cross-fertilize with the modern has now given way to an international "burolandschaft city-scape” (Frampton 1983, 17). Frampton's attack on totalizing forms of modern city planning is, to be sure, itself universalizing in that it posits "an apocalyptic thrust of modernization" that can no longer be avoided because "the ground in which the mytho-ethical nucleus of a society might take root has become eroded by the rapacity of development" (Frampton 1983, 17). Frampton wallows in the sterile uniformity of modern architecture, using the same broad brushes as Tom Wolfe in his scathing From Bauhaus to Our House (1981). The contradiction between the abstraction and sparseness 
of modern architecture and the civilization it serves leads both writers to express their longing for more traditional, locally inflected forms of building.

The above references to 'rootedness,' 'ground,' 'erosion,' etc. are significant in this context, and so is the idea of the 'rapacity' of development. Frampton's criticism of the bleak, standardized design of contemporary architecture echoes long-standing concerns about industrial civilization that reach as far back as the Romantic era. From September 1837 to December 1838, the English art critic John Ruskin had published a series of articles on architecture, known as The Poetry of Architecture, in which he argued that buildings should be respectful to their immediate environment and use local building materials. Ruskin's back-to-nature aesthetics, his critique of standardization and imitation in contemporary architectural design foreshadows aspects of Frampton's critical regionalism and his call for an "architecture of resistance" (Frampton 1983, 25) that does not give way to the dictates of modern technology. Moreover, arguments regarding the rapaciousness of modern civilization have been voiced all along by cultural critics from Thoreau to Marcuse and the Frankfurt School. In one way or another, they all take issue with capitalism's disregard for local cultural traditions and its inherent tendency towards an ever greater uniformity and standardization. ${ }^{5}$

It should also not go unnoticed that many of these critiques proffer recalcitrant, non-conformist artists, or as Ricoeur has it, 'scandalist' artists as an antidote to the leveling power of modern cultural formations. "All great artistic creations always begin with some scandal," Ricoeur writes in "Civilization and National Cultures," and it is for this reason that

the law of scandal answers the law of the 'false consciousness.' It is necessary to have scandals [...]. Such is the tragic law of the creation of a culture, a law diametrically opposed to the steady accumulation of tools which make up the civilization. (Ricoeur 1965, 281)

Insofar as he pits the creativity of artists against the forces of standardization and cultural deracination, what he calls - following Adorno - "false consciousness," Ricoeur subscribes to the Romantic notion of art as autonomous, as being outside of the cycles of production and accumulation which make up modern civilization. Because true artistic creation cannot be commissioned or programmed, it does not comply with the mechanics of technical reasoning. Rather than being an impediment to their cultural mission, it is precisely the lack of purpose and their distance from material conditions that enable artists to become a transformative voice of their national culture. "The artist," Ricoeur claims, "gives expression to

5 For a discussion of both Thoreau's and Heidegger's reconfiguration of place as well as their scathing critique of modern industrial culture, see Benesch (2012). 
his nation only if he does not intend it and if no one orders him to do it" (Ricoeur 1965, 281).

Yet if art appears to be deeply invested in local cultures and their respective traditions, the obvious inertia engrained in timeworn, unchanging cultural practices also poses a serious threat to the creative resources of a nation. Ricoeur acknowledges that risk by noting that any artistic creation informed by sedimented symbols and an unchanging cultural iconography runs the risk of becoming stale and trite. Unlike a set of tools or customs that merely accumulate and become integrated with the overall historical development of a region or nation, cultural tradition, as Ricoeur takes pains to explain, "stays alive only if it constantly creates itself anew" (Ricoeur 1965, 280). Like an organism that grows and continuously alters its shape, local cultures, though predicated on cultural continuity and identifiable cultural traditions, are also always subject to rejuvenation and renewal. It is this capacity of cultural tradition to constantly change and recreate itself that allows Ricoeur, and the critical regionalists that followed him, to highlight the diversity of local cultures in contrast to the staggering homogeneity of transnational technical civilization.

\section{The Homeless Spirit}

In his 1966 interview with the news weekly Der Spiegel, titled "Only a God Can Save Us," the German philosopher Martin Heidegger famously claimed that "according to our human experience and history, everything essential and everything great originated from the fact that man had a home and was rooted in tradition" (Heidegger 1993, 106). ${ }^{6}$ Heidegger had repeatedly emphasized that all great thinking must be rooted in the cultural traditions of a region or place, yet in the Spiegel-interview he coupled his praise of locally inflected forms of creativity with an especially harsh attack on contemporary art, and in particular modern

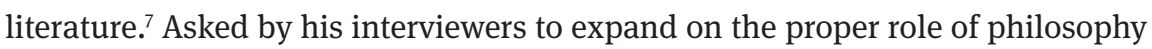
in the modern world, he insisted that neither philosophy nor the arts have the

6 The interview was originally recorded in 1966 yet released, on request of Heidegger, only after his death in 1976. Heidegger had agreed to discuss questions concerning his involvement with nationalist socialist politics during his time as rector of Freiburg University. Although these issues clearly dominated the interview, Heidegger used the occasion to review basic assumptions of his philosophical thinking, and in particular its relation to historical developments and modern society in general.

7 See, for example, his oft-quoted 1948 essay “Conversations on a Country Path about Thinking.” 
wherewithal to reverse the uprooting of man from the earth, as exemplified in the event of man's landing on the moon. Neither of them is equipped to undo the power of 'technicity' (Heidegger's term for the modern technosphere), the essence of which continuously escapes us and to which we have not yet responded in an appropriate way. Not only have philosophy and the arts failed "to effect any immediate change in the current state of the world" (Heidegger 1993, 107). With regard to the Herculean task of reorienting man towards a more encompassing understanding of being as a being in the world, Heidegger singles out contemporary literature as vastly "inadequate" if not "largely destructive" (Heidegger 1993, 106).

Given the insurmountable influence of technology on modern man, Heidegger ultimately concludes that "only a god can save us." And since we cannot 'think' this god, whatever form it might take, into being, the only possibility available to us is to "prepare a sort of readiness, through thinking and poetizing, for the appearance of the god, or for the absence of the god in the time of foundering [Untergang]; for in the face of the god who is absent, we founder" (Heidegger 1993, 107). Heidegger's conspicuous silence vis-à-vis the forces of modernization is as striking as it is paradoxical. For one, he holds that neither philosophy nor poetry and literature can play a major role in bringing about any kind of turn-around. Because man is existentially challenged "by a power which manifests itself in the essence of technology, a power which man himself does not control [...] philosophy is at an end" (Heidegger 1993, 107). Yet for another, he reminds us that if "the world cannot be what it is or the way that it is through man, neither can it be without man" (Heidegger 1993, 107). While it is true that mankind has set free the genie of technology, a force that will eventually undo our being-in-the-world, Being in its broadest, phenomenological sense still needs man "for its revelation, preservation, and formation” (Heidegger 1993, 107). Though highly skeptical of their capacity to actually alter the course of history, Heidegger still sees an important path left open to thinking and poetizing: namely, to assist man in overcoming the homelessness of his modern self by conjuring up a state of renewed 'at-home-ness' in the world.

The notion that thinking is intimately connected to the act of building a home and then dwelling in it is the topic of Heidegger's oft-quoted essay "Building Dwelling Thinking," published in 1951 in the wake of the housing shortage after World War II. All three activities turn on a particular relationship between human beings and the environment, and all three provide ways to become one with or at least acknowledge the environment as part and parcel of the human condition. It is important to note here that what connects thinking to building and dwelling, or rather to their physical manifestation as a 'building' and a 'home,' is more than 
merely symbolical. Just consider the various meanings - geographical, political, cultural, etc. - of a bridge. As Heidegger remarks,

the bridge, if it is a true bridge, is never first of all a mere bridge and then afterward a symbol. And just as little is the bridge in the first place exclusively a symbol, in the sense that it expresses something that strictly speaking does not belong to it [...]. The bridge is a thing and only that. (Heidegger 1971, 147, emphasis in the original)

Since we have long been accustomed to undervalue the nature of things, and to think of them as merely relative to some symbolic or practical meaning, we are no longer able to acknowledge things by and through their thingness. What this means is that the bridge, and by extension any building erected by an interaction of human ingenuity and the environment, is first and foremost a presencing or bringing into existence of what Heidegger, somewhat opaquely, calls the "fourfold" (das Geviert). Representing the essential unity and conjunction of earth, sky, humans (mortals), and divinities (immortals), the fourfold is made visible and actuated by way of building and dwelling. Because bridges urge us to reflect on the relation of man and space, to recognize that space "is not an external object nor an inner experience" (Heidegger 1971, 156), and that "man's relation to locations, and through locations to spaces, inheres in his dwelling" (Heidegger 1971, 157), bridges are space-making buildings in a double sense: they at once express the fourfold symbolically and they make room for it by way of their physical extension as built objects.

Heidegger goes to great lengths in arguing that dwelling and building are inextricably bonded together, and that "only if we are capable of dwelling, only then can we build" (Heidegger 1971, 159). In each instance there is more involved than merely the immediate purpose of creating a physical shelter and then using it as protection against an intemperate environment. Traditional Black Forest farmhouses architecturally and structurally conjoin the various elements of the fourfold by letting "earth and heaven, divinities and mortals enter in simple oneness into things [i.e. the farmhouse]" (Heidegger 1971, 159, emphasis in the original). Building properly and dwelling properly are mutually dependent, and both are symbolically and physically made present in the thingness of the built object. They are thus "the basic character of Being in keeping with which mortals exist" (Heidegger 1971, 159). Moreover, both are closely tied to thinking in that all three are ways of expressing and becoming aware of man's implementation in the fourfold. Only when we realize that "the one as much as the other comes from the workshop of long experience and incessant practice” (Heidegger 1971, 159-160), only then can we hope to overcome the diasporic homelessness of modern man. Obviously, Heidegger's understanding of building and dwelling, as well as of the 
kind of thinking it necessitates, is predicated on longstanding cultural traditions and their concretization as locally inspired buildings or 'homes.'8

By exposing the composite nature of places, which - when brought into contiguity by way of building - create larger, extended spaces, Heidegger turns the tables on modernity's valorization of space. He also posits that it is man's interaction with the environment in the form of building that defines our humanity. As human beings we do not inhabit preexisting spaces, rather we construct spaces through the act of building: "building, by virtue of constructing locations, is a founding and joining of spaces" (Heidegger 1971, 158). His, then, is a placebound, existential philosophy that aims at reattaching - qua thinking as building - the modern homeless spirit to local cultural traditions. The idea of home, of a built space rooted in and representative of the fourfold, is paramount here. Yet not all buildings fulfill this prerequisite. To provide a home for modern man, it does not suffice to simply promote the building of houses. The real plight is not that there is a housing shortage, the real "dwelling" plight lies in this that "mortals ever search anew for the nature of dwelling, that they must ever learn to dwell" (Heidegger 1971, 160, emphasis in the original). If modern man is 'homeless' this is precisely because we have not only forgotten how to dwell but because we do not even think of not dwelling properly as the plight that ails us. As soon as we give thought to our homelessness, we have already made a first step towards realizing the full potential of dwelling. How can we do this? Though Heidegger offers little in terms of practical solutions, it becomes clear that he wants us to embrace the notion of human life as fundamentally predicated on dwelling, to think of dwelling as a form of being-in-the-world and making it a 'home.'

Heidegger's definition of being as a form of dwelling is clearly at odds with the modern belief in human progress and the possibility of improving the conditions of life for all men. He has little to say about science and technology other than mythologizing them and blaming them for the demise of Western philosophy as he understands it. Insofar as he privileges local traditions over cultural change, concrete places over transnational spaces, and the rootedness of farm life over urban deracination and alienation, his is an entirely nostalgic, antimodern stance. As the Jewish philosopher Emmanuel Levinas points out, Heidegger's skepticism as to the benefits of modern life, his denial of its liberating, utopian potential, betrays a deep-seated elitist and antidemocratic strain of thought. In a short piece called "Heidegger, Gagarin, and Us," which originally appeared in 1963 as part of an extended collection of essays on Judaism, Levinas attacks

8 An earlier, equally 'wholistic' notion of dwelling can be found in Henry David Thoreau's transcendentalist classic Walden: Or Life in the Woods (1854), particularly in chapter II, "Where I lived, and What I lived For." 
Heidegger and his followers for their naïve attempts at recovering a 'natural' world that was long lost and probably never even existed. His harsh criticism of 'Heideggarians' is particularly interesting in that it posits - like Heidegger - a preponderance of science and technology in the modern world, while ascribing to this condition diametrically opposed effects and consequences.

Levinas' description of the nostalgic mindset of Heideggarians is especially revealing, and thus deserves to be quoted at length:

[Heideggarians] would like man to rediscover the world [...]. To rediscover the world means to rediscover a childhood mysteriously snuggled up inside the Place, to open up to the light of great landscapes, the fascination of nature, and the delight of camping in the mountains. It means to follow a path that winds its way through fields, to feel the unity created by the bridge that links the two river banks and by the architecture of buildings, the presence of the tree, the chiaroscuro of the forests, the mystery of things [...]. The very Being of reality will reveal itself behind these privileged experiences, giving and trusting itself into man's keeping. And man, the keeper of Being, will derive from this grace his existence and his truth. (Levinas 1990, 231-232, emphasis in the original)

'Childhood,' 'Place,' 'delight of landscapes and camping,' 'privileged experiences,' etc. - by relaying Heidegger's thinking to the romantic imagination of adolescents - 'privileged' male adolescents, that is - where things and sites are riddled with the mysterious, pristine, transcendental, Levinas exposes Heidegger's world view for what it is: at times utterly naïve and presumptuous. ${ }^{9}$ Yet worse than the obvious infantilism and verbosity of some of Heidegger's essays is his intrinsic divisiveness, his tendency to group people into those who are place-bound and those who are dispersed and 'home-less,' for whom there is no place to become attached to, and who therefore remain outsiders and strangers:

One's implementation in a landscape, one's attachment to Place, without which the universe would become insignificant and would scarcely exist, is the very splitting of humanity into natives and strangers. And in this light technology is less dangerous than the spirits [génies] of the Place. (Levinas 1990, 232, emphasis in the original)

By dividing the world into native dwellers and nomadic outsiders, Heidegger's phenomenological approach, Levinas contends, is bound to fall prey to the specters of totalitarianism. What is more, because of its fear of technology it will never adequately account for the complexity of the modern world, including the liberating role of technology itself. If for Heidegger the attachment to places provides an antidote to the alienating forces of modernity, for Levinas it

9 “The fable spoken by the first language of the world," Levinas quips, "presupposes links that are more subtle, numerous and profound" (Levinas 1990, 232). 
is precisely through technology that we are able to escape the prison of place: "Technology wrenches us out of the Heideggerian world and the superstitions surrounding Place” (Levinas 1990, 232-233, emphasis in the original). Though it remains unclear what exactly it is that makes technology such a liberating force, in providing new ways for perceiving "men outside the situation in which they are placed” (Levinas 1990, 233), it represents more of an opportunity for humanity than its inexorable downfall.

Given his own Jewish background, Levinas is highly suspicious of Heidegger's celebration of rootedness and the archaic world of rural life. He prefers cities, urban spaces "in which one meets people" (Levinas 1990, 233), to the countryside. And while Heidegger stresses the connection between men and the earth, Levinas seems to foreground social interaction among people (not things). Judaism, he reminds us, has always been free of the shackles of place. Not only was it difficult for the Jewish Diaspora to put down roots and become attached to places. What is more, the Talmud explicitly demands of the individual to offer food, drink, and shelter to other men. Rather than invoking our embeddedness in nature, Judaism emphasizes human relationships and solidarity. Contrary to Christianity which integrates the local saint with a universal religious system but which remains essentially rooted in geography and place, the Jewish disregard for origins and roots allows for a more radical, liberating form of universality. Herein also lies the achievement of Russian cosmonaut Yuri Gagarin, the first human in space: "not in the sporting achievement of having gone further than the others and broken the world records for height and speed [...] what perhaps counts most of all," Levinas muses, "is that he left the Place" (Levinas 1990, 233). For Levinas, then, the modern world is divided by two opposing worldviews: the worldview of Christianity and the Heideggarians, who continue "to give piety roots, nurturing itself on landscapes and memories culled from family, tribe and nation," and the worldview of Judaism and the Talmud, which did not idolize saints and local cults but "demanded that they be destroyed" (Levinas 1990, 234). Like technology Judaism is a liberator and true representative of modernity: it has demystified the universe and, thereby, has freed Nature from the spell of superstitiousness and mysticism. And while Heidegger and his followers remain spellbound by an antimodern mythology of place, Gagarin and the rest of us, thus seems to be the message of Levinas' critique, will move on to make the world, if not the entire universe, their/our home.

\section{What is Home then, You Might Wonder?}

Heidegger's and Levinas' approach to place and the influence of technology on modern civilization differ in that the former stresses the importance of roots over 
routes and demonizes technology as a negative influence on humans and their relationship with the natural world. Levinas, on the other hand, not only distrusts Heidegger's phenomenology of place, which he believes to be both naïve and dangerous because it widens the gap between natives and the Other, those who are exempt from the privilege of place. He also acknowledges the liberating potential of technology, of city life, and of itinerant, nomadic lifestyles, all of which necessitate human interaction and solidarity. Both positions have come to demarcate major fault lines in debates about the future of capitalism and modern societies; and both involve a wide range of issues, from mobility to land rights, from cultural heritage to transnational migration, from agriculture to delocalized, corporate forms of production. Above all, however, both posit very different views of what we might call a 'home,' and how that home is connected to forms of dwelling and, to use Heidegger's phrasing, our being-in-the-world.

The notion of 'home' and what it might entail has also been a prominent topic in recent narrative fiction. For reasons mentioned above, Americans have long struggled with the idea of founding a home. The European concept of 'dwelling' became a contested, at best limited concept when transferred to American soil. From early settlements to suburban grid homes, from gated communities to trailer parks for the 'roving' retirees, its meaning keeps on shifting. Whether it denotes the place 'where you lay your head,' according to a well-known proverb, or whether it refers to a more tribal sense of belonging that involves an extended group of people, a region, or even an entire country, much of our understanding of home is informed by narrative, by stories about both homes and the homeless. At the outset of Richard Ford's 2006 novel The Lay of the Land the narrator, a New Jersey realtor, ponders the various aspects of home only to find it an almost impossible task to define its true meaning:

\footnotetext{
What is home then, you might wonder? The place you first see daylight, or the place you choose for yourself? Or is it the someplace you just can't keep from going back to, though the air there's grown less breathable, the future's over, where they really don't want you back, and where you once left on a breeze without a rearward glance? Home? Home's a musable concept if you're born to one place, as I was (the syrup-aired southern coast), educated to another (the glaciated mid-continent), come full stop in a third - then spend years finding suitable 'homes' for others. (Ford 2006, 15-16)
}

There is little doubt that in a fast changing globalized world such as today's, home has become a multi-faceted concept that people not all too easily agree upon. Where do we go from here? And how can we make the world, as both Heidegger and Levinas suggest, our home without simultaneously destroying it? How can we learn to dwell properly without succumbing to a highly problematic ideology of place that turns many of us into strangers and outsiders? How to overcome 
the fallacies of place and not give in to an unbridled regime of technology and its corollary, a rapidly shrinking, globally interconnected and, at the same time, socially and culturally divided world? What are the narratives that need to be told in order to regain both a sense of place and a sense of home, however volatile and fragile it might be?

Obviously, there is no easy solution to these questions. To accommodate universal mobility and constant change poses significant challenges for both writers and thinkers. Taken on their own, neither Heidegger's phenomenological mysticism nor Levinas' embracement of technology as an enlightening, liberating force seems capable of adequately dealing with these new challenges. Since places are, at once, valuable (i.e. as real estate) and culturally de- or undervalued, it takes more than merely a patch of land to build a home. It takes the imagination. This at least is the topic of Curtis White's narrative collage The Idea of Home, first published in 1992. White's fictional suburb of San Lorenzo, California, where its author grew up during the 1950s and 1960s, clearly does not meet one's expectations of "a place where humans can live." Therefore, White embarks on a narrative journey to imagine that place, and make it "more desirable than the failure which we presently inhabit" (White 2004, 9). White knows that he is after "a real nowhere, a realizable illusion" (White 2004, 10) and thus relates his narrative project, in the final chapter, to the shadowy realm of artistic illusion where painted haystacks reek with the odor of the real thing, just as sweet as he remembered them when, as a child, his village was visited by hay storms. It is important to keep in mind that White's is in no way an uncritical, nostalgic enterprise; rather he stresses the fictitiousness of all memory, and, by extension, of concepts such as 'home,' 'belonging,' and 'place.' As Levinas contends, to experience a sense of 'at-home-ness' with the world may have, after all, more to do with people than with places.

This is also true of the post-apocalyptic world in Cormac McCarthy's novel The Road. In an environment devastated by ecological disaster, places have not only lost their former magic. To recover one's identity, to reassure the self that everything is in place, it is other people, our own kin, to who we look for guidance and support:

He sat looking at the map. The man watched him. He thought he knew what that was about. He'd poured over maps as a child, keeping one finger on the town where he lived. Just as he would look up his family in the phone directory. Themselves among others, everything in its place. Justified in the world. (McCarthy 2006, 182)

In times of crises, it is this experience of community and bonding, the creation of a shared life world inhabited by human beings that matters. Places are an integral 
part of that life world, yet willed into existence only by way of human imagination. The map is not the territory, and places do not exist for and on their own. And because both places and the idea of home are concepts culled from the imagination, it is narratives that tell us how to live properly, with and in them.

\section{Works Cited}

Benesch, Klaus (2012). "Cultural Immobility: Thoreau, Heidegger, and the Modern Politics of Place." Amerikastudien/American Studies 57.3, 403-418.

Berry, Wendell (1978). The Unsettling of America: Culture \& Agriculture. New York, NY: Avon Books.

Botz-Bornstein, Thorsten (2010). "Is Critical Regionalist Philosophy Possible? Some Meta-Philosophical Considerations." Comparative and Continental Philosophy 2.1, 1-15. Canizaro, Vincent B., gen. ed. (2007). Architectural Regionalism: Collected Writings on Place, Identity, Modernity, and Tradition. Princeton, NJ: Princeton Architectural Press.

Flink, James J. (1975). The Car Culture. Cambridge, MA: MIT Press.

Flink, James J. (1988). The Automobile Age. Cambridge, MA: MIT Press.

Ford, Richard (2006). The Lay of the Land. New York, NY: Knopf.

Frampton, Kenneth (1983). "Towards a Critical Regionalism: Six Points for an Architecture of Resistance.” Hal Foster, ed. The Anti-Aesthetic: Essays on Postmodern Culture. Seattle, OE: Bay Press, 16-30.

Hegel, Georg Wilhelm Friedrich (1956). The Philosophy of History. Trans. John Sibree. New York, NY: Dover Publications.

Heidegger, Martin (1971 [1951]). “Building Dwelling Thinking.” Poetry, Language, Thought. Trans. Albert Hofstadter. New York, NY: Harper, 141-160.

Heidegger, Martin (1966 [1976]). “Conversations on a Country Path about Thinking.” Discourse on Thinking. Trans. John M. Anderson and E. Hans Freund. New York, NY: Harper and Row, 58-90.

Heidegger, Martin (1993 [1966]). “Only a God Can Save Us: Der Spiegel's Interview with Martin Heidegger.” Richard Wolin, ed. The Heidegger Controversy: A Critical Reader. Cambridge, MA: MIT Press, 91-114.

Latour, Bruno ([1991] 1993). We Have Never Been Modern. Trans. Catherine Porter. Cambridge, MA: Harvard University Press.

Levinas, Emmanuel (1990). “Heidegger, Gagarin, and Us.” Difficult Freedom: Essays in Judaism. Trans. Sean Hand. Baltimore, MD: Johns Hopkins University Press, 231-234.

McCarthy, Cormac (2006). The Road. New York, NY: Vintage.

Nye, David (1994). American Technological Sublime. Cambridge, MA: MIT Press.

Nye, David (1997). Narratives and Spaces: Technology and the Construction of American Culture. Exeter: University of Exeter Press.

Powell, Douglas (2007). Critical Regionalism: Connecting Politics and Culture in the American Landscape. Chapel Hill, NC: University of North Carolina Press.

Ransom, Jon Crowe (1977 [1930]). “Reconstructed But Unregenerate." I'll Take My Stand: The South and the Agrarian Tradition. Baton Rouge, LA: Louisiana State University Press, 1-27. Ransom, Jon Crowe (1934). “The Aesthetic of Regionalism.” American Review II, 290-310. 
Ricoeur, Paul (1965 [1961]). “Universal Civilization and National Cultures.” Paul Ricoeur, History and Truth. Trans. Chast A. Kelbley. Evanston, IL: Northwestern University Press, 271-284.

Ruskin, John (1903). "The Poetry of Architecture; Or The Architecture of the Nations of Europe Considered in its Association with Natural Scenery and National Character." The Complete Works of John Ruskin. Vol. 1 (Poetry of Architecture, Seven Lamps, Modern Painters). New York, NY/Chicago, IL: National Library Association. Project Gutenberg (release 2006) <https://www.gutenberg.org/files/17774/17774-h/17774-h.htm> (October 20, 2015).

Schäfer, Wolf (2001). “Global Civilization and Local Cultures: A Crude Look at the Whole.” International Sociology 16.3, 301-319.

Seiler, Cotton (2008). Republic of Drivers: A Cultural History of Automobility in America. Chicago, IL: University of Chicago Press.

Tichi, Cecelia (1979). New World, New Earth: Environmental Reform in American Literature from the Puritans through Whitman. New Haven, CT: Yale University Press.

White, Curtis (2004 [1992]). The Idea of Home. Normal, IL/London: Dalkey Archive Press. Wolfe, Tom (1981). From Bauhaus to Our House. New York, NY: Farrar, Straus and Giroux. 